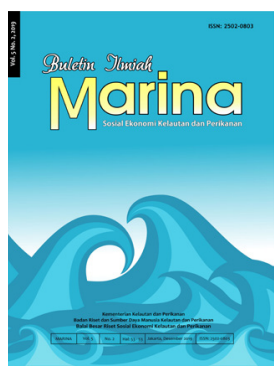

BULETIN ILMIAH MARINA

SOSIAL EKONOMI KELAUTAN DAN PERIKANAN

http://ejournal-balitbang.kkp.go.id/index.php/mra

p-ISSN: 2502-0803

e-ISSN: 2541-2930

Nomor Akreditasi: 10/E/KPT/2019

\title{
PENGARUH MANAJEMEN RANTAI PASOK TERHADAP PERFORMA USAHA BUDI DAYA UDANG VANAME DI PROVINSI BALI DAN JAWA TIMUR
}

\section{The Effect of Supply Chain Management on The Business Performance of Vaname Shrimp Farming in The Province of Bali and East Java}

\author{
*Rismutia Hayu Deswati, Lathifatul Rosyidah, dan Tenny Apriliani \\ Balai Besar Riset Sosial Ekonomi Kelautan dan Perikanan \\ Gedung BRSDM KP I Lt. 4 \\ Jalan Pasir Putih Nomor 1 Ancol Timur, Jakarta Utara, Indonesia \\ Telp: (021) 64711583 Fax: 64700924
}

Diterima tanggal: 20 Desember 2019 Diterima setelah perbaikan: 17 Desember 2020

Disetujui terbit: 21 Desember 2020

\begin{abstract}
ABSTRAK
Udang vaname merupakan salah satu komoditas ekspor unggulan Indonesia di pasar internasional. Udang vaname yang diekspor merupakan hasil produksi dari usaha budi daya yang tersebar di berbagai provinsi di Indonesia sehingga dibutuhkan rantai pasok yang optimal untuk mendukung kelancaran usaha budi daya tersebut. Tujuan dari penelitian ini untuk menganalisis pengaruh manajemen rantai pasokan terhadap keunggulan bersaing suatu usaha budi daya udang vaname dan dampak terhadap performa usaha tersebut. Lokasi penelitian adalah Provinsi Jawa Timur dan Bali karena konektivitas yang kuat antara masing-masing pembudi daya di kedua lokasi tersebut. Data yang dikumpulkan diverifikasi kemudian dianalisis menggunakan pendekatan Structural Equation Model (SEM). Hasil dari analisis menemukan bahwa variabel hubungan dengan pemasok dan modal manusia berpengaruh positif terhadap keunggulan bersaing pembudi daya dan juga berpengaruh positif kepada performa usaha budi daya tersebut. Variabel hubungan dengan pelanggan tidak berpengaruh baik terhadap keunggulan bersaing maupun performa usaha. Dari hasil ini diharapkan pemerintah bisa mengintervensi dalam bentuk perbaikan manajemen rantai pasokan udang vaname dengan meningkatkan kompetensi masing-masing anggota rantai pasok sehingga dapat optimal pada posisinya.
\end{abstract}

Kata Kunci: performa usaha; budi daya; udang vaname; rantai pasok; structural equation model

\section{ABSTRACT}

Vaname is one of Indonesia's leading export commodities in the international market. The exported vaname are the products from aquaculture business which are spread in various provinces in Indonesia, so an optimal supply chain is needed to support this business. The purpose of this study is to analyze supply chain management affects the competitive advantage of a vaname farming business and the impact on the performance of the business. The research sites are East Java and Bali because of the strong connectivity between each farmer in both locations. The collected data is verified and then analyzed using the Structural Equation Model (SEM) approach. The results of the analysis concluded that the relationship between suppliers and human capital variables had a positive effect on the competitive advantage of farmers and also had a positive effect on the performance of the aquaculture business. While the relationship with customer variables do not affect both competitive advantage and business performance. From this result, the government is expected to be able to intervene in the form of improved management of the vaname supply chain by increasing the competence of each member of the supply chain so that it can be optimally positioned.

Keywords: business performance; aquaculture; vaname; supply chain; structural equation model 


\section{PENDAHULUAN}

\section{Latar Belakang}

Udang vaname saat ini menjadi salah satu komoditas ekspor unggulan Indonesia yang terlihat dari prospek pasarnya yang masih potensial. Sejak tahun 2019, Kementerian Kelautan dan Perikanan telah menyiapkan langkah strategis untuk meningkatkan daya saing vaname ini di pasar internasional. Salah satunya dengan melakukan klasterisasi tambak udang dalam rangka mengembangkan prinsip budi daya udang yang bertanggung jawab, ramah lingkungan, dan berkelanjutan. Namun, pertanyaan yang mengusik apakah sebenarnya kondisi usaha budi daya vaname di Indonesia juga sudah siap untuk bersaing dengan negara-negara lainnya yang semakin banyak jumlahnya. Permasalahan utama yang melilit budi daya udang vaname terletak pada rantai pasok yang belum baik dan optimal dalam pelaksanaannya.

Brown (2003) dalam penelitiannya menyampaikan bahwa pengelolaan rantai pasok dalam agroindustri didefinisikan sebagai hubungan kerja sama antara produsen, pengolah, dan pedagang retail dalam memberikan jaminan serta meminimalkan biaya produksi. Persaingan usaha yang tinggi termasuk untuk komoditas udang vaname ini menempatkan para pembudi daya pada kondisi dengan keunggulan bersaing tidak dapat dicapai hanya dengan perbaikan internal saja. Perusahaan harus mampu menciptakan keunggulan kompetitif agar dapat menghasilkan nilai ekonomis bagi perusahaan yang lebih baik daripada pesaing (Barney dan Hesterley, 2008). Salah satu faktor yang menunjukkan suatu usaha memiliki keunggulan kompetitif atau daya saing yang tinggi dilihat dari kinerja integrasi masingmasing anggota rantai pasoknya (Adha, 2017). Oleh karena itu, diperlukan peran serta seluruh pihak dari produsen yang memproduksi barang jadi, jaringan distribusi yang akan menyampaikan produk ke tangan pelanggan, sampai hubungan antara penyedia produk dengan para pelanggan akhir, atau yang biasanya disebut dengan manajemen rantai pasokan.

Bentuk dasar dari sebuah rantai pasok terdiri dari beberapa komponen utama yang terdiri dari pemasok (supplier), industri atau usaha, gudang dan pusat distribusi (warehouse and distribution center), pedagang besar (wholesaler), pedagang eceran dengan tujuan akhirnya adalah memenuhi permintaan dari konsumen akhir (Simchi-Levi, Kaminsky, \& Simchi-Levi, 2008). Manajemen rantai pasokan adalah sebuah sistem yang melibatkan proses produksi, pengiriman, penyimpanan, distribusi, dan penjualan produk dalam rangka memenuhi permintaan akan produk tersebut, rantai pasokan di dalamnya termasuk seluruh proses dan kegiatan yang terlibat di dalam penyampaian produk tersebut sampai ke tangan pemakai konsumen (Wuwung, 2013). Manajemen rantai pasokan yang baik terlihat dari kemitraan rantai pasok yang terbentuk karena kemitraan menghasilkan pengaruh sinergitas fungsi bisnis antar perusahaan pada keseluruhan rantai (Mentzer, 2008).

Permasalahan rantai pasok udang vaname di Indonesia adalah jarak lokasi antara tambak, hatchery, dan daerah pemasaran yang berjauhan menyebabkan besarnya biaya distribusi yang harus ditanggung masing-masing pelaku usaha. Selain itu, Indonesia juga belum mampu menghasilkan induk udang vaname lokal sehingga pembudi daya masih tergantung pada ketersediaan induk dari luar negeri. Kondisi tersebut yang akhirnya membuat anggota rantai pasok udang yang terlibat meningkatkan harga jual produk mereka. Tingginya harga jual ini akhirnya menjadi salah satu kelemahan udang Indonesia di pasar internasional karena dengan kualitas yang sama, udang yang dihasilkan negara lain, misalkan India jauh lebih murah. Fenomena tersebut menunjukkan bahwa kemitraan rantai pasok atau manajemen rantai pasok merupakan sumber potensial dari daya saing (Grant, 2012; Gunasekaran \& Ngai, 2012; Hassini, Surti, dan Searcy, 2012). Berdasarkan fenomena tersebut, tujuan penelitian difokuskan untuk mengukur pengaruh manajemen rantai pasokan terhadap kinerja dari usaha budi daya udang vaname.

\section{Pendekatan IImiah}

Pujawan \& Mahendrawati (2010) menjelaskan bahwa pentingnya peran semua pihak mulai dari supplier, manufacturer, distributor, retailer, dan customer dalam menciptakan produk yang murah, berkualitas, dan cepat inilah yang kemudian melahirkan konsep baru, yaitu Supply Chain Management. Penelitian mengenai manajemen rantai pasokan ini juga merujuk pada pendapat Rahmasari (2011), bahwa manajemen rantai pasokan yang efektif dan optimal dapat meningkatkan produktivitas, pangsa pasar, dan pertumbuhan. Praktek manajemen rantai pasok 
terbagi menjadi tiga konsep utama, yaitu hubungan dengan pelanggan, hubungan dengan pemasok, dan hubungan dalam perusahaan (Lee, Kwon, \& Severance, 2007; Banerjee \& Mishra, 2015). Pentingnya praktek manajemen rantai pasok yang baik menjadi salah satu strategi bersaing yang dimiliki setiap pelaku usaha untuk mempertahankan tingkat keuntungan dan posisi ketika menghadapi persaingan (Goyal \& Cardenas-Barron, 2001).

Variabel yang digunakan dibangun berdasarkan tiga konsep utama manajemen rantai pasok di atas serta pengaruh dari keunggulan bersaing yang ada terhadap performa usaha budi daya udang vaname tersebut, yaitu:

\begin{tabular}{|c|c|}
\hline$H_{1}=$ & $\begin{array}{l}\text { variabel hubungan dengan pelanggan } \\
\text { (HDPI) berpengaruh positif terhadap } \\
\text { keunggulan bersaing }\end{array}$ \\
\hline $\mathrm{H}_{2}=$ & $\begin{array}{l}\text { variabel hubungan dengan pemasok } \\
(\mathrm{HDPm}) \text { berpengaruh positif terhadap } \\
\text { keunggulan bersaing }\end{array}$ \\
\hline $\mathrm{H}_{3}=$ & $\begin{array}{l}\text { variabel modal manusia (MM) berpengaru } \\
\text { positif terhadap keunggulan bersaing }\end{array}$ \\
\hline $\mathrm{H}_{4}$ & $\begin{array}{l}\text { variabel keunggulan bersaing (KB) } \\
\text { berpengaruh positif terhadap performa } \\
\text { usaha }\end{array}$ \\
\hline
\end{tabular}

Penelitian dilakukan di Provinsi Bali dengan fokus pada Kabupaten Buleleng dan Jembrana serta Provinsi Jawa Timur di Kabupaten
Banyuwangi dan Kota Surabaya. Pemilihan lokasi dilakukan secara sengaja berdasarkan informasi dari Direktorat Jenderal Perikanan Budidaya, Kementerian Kelautan dan Perikanan, bahwa Provinsi Bali merupakan salah satu lokasi dengan produksi benih dan udang vaname yang potensial, sedangkan Provinsi Jawa Timur selain produksinya tinggi juga merupakan daerah pemasaran untuk komoditas ini. Penelitian dilakukan pada bulan April-Mei tahun 2019 yang merupakan bagian dari penelitian besar mengenai sistem logistik udang vaname secara nasional.

Data primer diperoleh melalui pengamatan langsung dan wawancara dengan responden. Responden terdiri atas pembudi daya udang, pedagang kecil, pedagang besar atau supplier, dan konsumen akhir baik dari rumah tangga maupun hotel dan restoran. Sedangkan data sekunder berupa hasil studi pustaka mengenai karakteristik wilayah dan usaha budi daya udang vaname di Bali, Jawa Timur, dan sekitarnya. Sumber data sekunder berasal dari BKIPM, Balai Besar Riset Budidaya Laut dan Penyuluhan Perikanan, Dinas Kelautan dan Perikanan provinsi serta beberapa instansi terkait lainnya.

Dalam penelitian ini, variabel yang digunakan terdiri dari variabel dependen, variabel intervening atau moderasi, dan variabel independen. Variabel dependen yang digunakan adalah performa usaha

Tabel 1. Definisi Operasional dan Indikator Pengukuran Variabel Penelitian.

\begin{tabular}{|c|c|c|}
\hline Nama Variabel & Definisi Variabel & Indikator \\
\hline $\begin{array}{l}\text { Hubungan dengan } \\
\text { pelanggan }(X 1)\end{array}$ & $\begin{array}{l}\text { Hubungan dengan pelanggan mengukur } \\
\text { tentang perencanaan, pengimplementasian, } \\
\text { dan pengevaluasian hubungan yang } \\
\text { berhasil antara penyedia dan penerima dari } \\
\text { hulu sampai ke hilir didalam rantai pasokan } \\
\text { (Lee, et al., 2007) }\end{array}$ & $\begin{array}{l}\text { 1. Pertukaran informasi yang baik } \\
\text { 2. Pengiriman barang yang sesuai di waktu yang tepat } \\
\text { 3. Pengiriman barang yang sesuai dengan kuantitas yang } \\
\text { tepat } \\
\text { 4. Pengiriman barang yang sesuai dengan invoice yang } \\
\text { tepat } \\
\text { 5. Komitmen pada perjanjian jual beli yang sudah disepakati }\end{array}$ \\
\hline $\begin{array}{l}\text { Hubungan dengan } \\
\text { pemasok }(X 2)\end{array}$ & $\begin{array}{l}\text { Hubungan dengan pemasok ini berurusan } \\
\text { dengan melibatkan pemasok dalam tahap } \\
\text { perencanaan produk baru, mengembangkan } \\
\text { sistem order yang memiliki respon cepat } \\
\text { dengan pemasok, menempatkan jaringan } \\
\text { pemasok dengan pengiriman yang dapat } \\
\text { diandalkan, serta pertukaran informasi } \\
\text { dengan pemasok (Lee, et al., 2007) }\end{array}$ & $\begin{array}{l}\text { 1. Respon permintaan input produksi (pakan dan benih) } \\
\text { 2. Kualitas pertukaran informasi } \\
\text { 3. Sistem pengiriman yang diandalkan } \\
\text { 4. Rasa percaya antara kedua belah pihak }\end{array}$ \\
\hline Modal Manusia (X3) & $\begin{array}{l}\text { Keseluruhan dari pengetahuan dan } \\
\text { pengalaman yang dimiliki karyawan } \\
\text { perusahaan (Todericiu \& Stanit, 2015) }\end{array}$ & $\begin{array}{l}\text { 1. Ketanggapan } \\
\text { 2. Pemahaman } \\
\text { 3. Kejujuran } \\
\text { 4. Kemampuan untuk budi daya } \\
\text { 5. Mampu berkomunikasi dengan baik }\end{array}$ \\
\hline $\begin{array}{l}\text { Keunggulan Bersaing } \\
(Z)\end{array}$ & $\begin{array}{l}\text { Sebuah usaha memiliki indikator tertentu } \\
\text { yang berbeda atau tidak dimiliki usaha lain }\end{array}$ & $\begin{array}{l}\text { 1. Kualitas produk } \\
\text { 2. Fleksibilitas pasar } \\
\text { 3. Sistem budi daya sesuai CBIB }\end{array}$ \\
\hline $\begin{array}{l}\text { Performa Usaha Budi } \\
\text { daya }(Y)\end{array}$ & $\begin{array}{l}\text { Output atau hasil yang diperoleh dari usaha } \\
\text { budi daya }\end{array}$ & $\begin{array}{l}\text { 1. Omset } \\
\text { 2. Keuntungan } \\
\text { 3. Kualitas produk } \\
\text { 4. Perputaran persediaan }\end{array}$ \\
\hline
\end{tabular}


budi daya, variabel intervening atau moderasi yang digunakan adalah keunggulan bersaing dan variabel independen yang digunakan adalah hubungan dengan pelanggan, hubungan dengan pemasok, dan modal manusia dengan beberapa indikator seperti yang tercantum pada Tabel 1.

Pengumpulan data penelitian dilakukan dengan duacara, yaitu wawancara dan studipustaka. Pengumpulan data primer dilakukan dengan metode penelitian survei, yaitu metode yang digunakan untuk mendapatkan data dari tempat tertentu yang alamiah dan peneliti menggunakan bantuan, seperti kuesioner dan angket dalam pengumpulan datanya (Sugiyono, 2013). Data yang terkumpul kemudian dianalisis dengan menggunakan analisis deskriptif untuk mengidentifikasi rantai pasok udang vaname di Bali. Pengaruh manajemen rantai pasok terhadap keunggulan bersaing usaha budi daya dan hubungannya terhadap performa usaha budi daya udang vaname dianalisis dengan menggunakan pendekatan Structural Equation Model (SEM). Pendekatan SEM dirasa tepat untuk menganalisis penelitian ini karena variabel yang digunakan mayoritas bersifat laten (variabel yang tidak dapat diukur secara langsung). Kurang tepat jika alat analisis yang digunakan seperti analisis regresi karena metode ini tidak memperhitungkan kesalahan pengukuran (measurement error). Sementara itu, jika kesalahan pengukuran tersebut tidak diperhitungkan maka koefisien jalur bisa menjadi bias (Smith \& Langfield, 2004; Hair 2011).

Secara umum, kerangka teoritis untuk penelitian ini seperti dijelaskan pada Gambar 1. Variabel keunggulan bersaing menjadi variabel intervening antara variabel independen dengan variabel dependen.

\section{KARAKTERISTIK BUDI DAYA UDANG VANAME DI PROVINSI BALI}

Sektor kelautan dan perikanan merupakan salah satu sektor non migas yang menjanjikan dan berpotensi bagi masyarakat di Bali. Potensi kelautan dan letak geografisnya menjadikan Bali sebagai salah satu daerah wisata air yang berdaya saing tinggi di kancah internasional. Tidak terkecuali dari potensi perikanan baik dari perikanan tangkap maupun budi daya. Kontribusi sektor perikanan menunjukkan peningkatan setiap tahunnya bagi PDRB provinsi, tercatat pada akhir tahun 2018 mencapai 4,32\% atau meningkat sekitar $0,11 \%$ dari tahun sebelumnya (BPS Provinsi Bali, 2019). Angka tersebut menandakan secara riil terjadi peningkatan produksi dan jumlah rumah tangga perikanan yang terdapat di provinsi ini. Dari Gambar 2 terlihat bahwa jumlah produksi perikanan baik tangkap maupun budi daya mengalami perubahan yang fluktuatif namun cenderung bertambah. Bahkan produksi perikanan budi daya tahun 2017 mengalami peningkatan mencapai $47 \%$ dari tahun sebelumnya (BPS Provinsi Bali, 2018).

Gambar 2 menunjukkan bahwa meskipun provinsi ini memiliki potensi perikanan tangkap yang cukup tinggi namun ternyata total produksinya masih kalah dibandingkan dengan produksi budi dayanya. Secara khusus, perikanan budi daya di Bali penyumbang produksi tertinggi dari budi daya laut dengan komoditas utamanya rumput laut

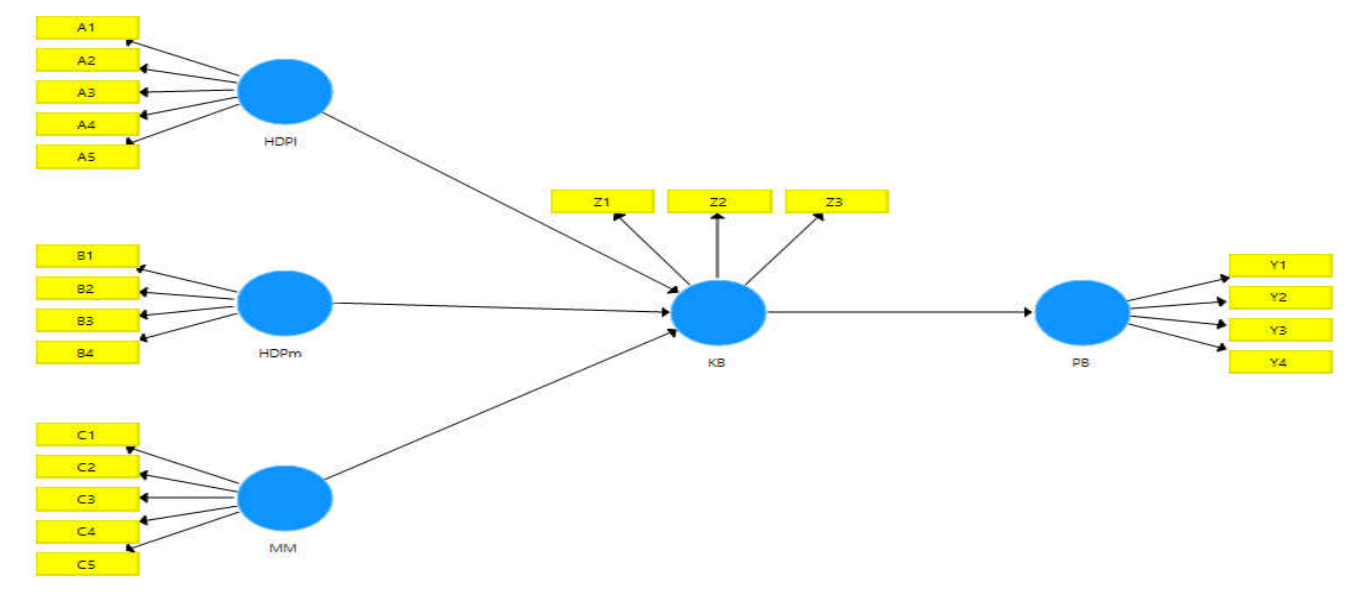

Gambar 1. Kerangka Teoritis Pengaruh Manajemen Rantai Pasok terhadap Performa Usaha Budi Daya Udang Vaname di Bali dan Jawa Timur.

Sumber: Modifikasi dari Maddeppungeng (2017) 


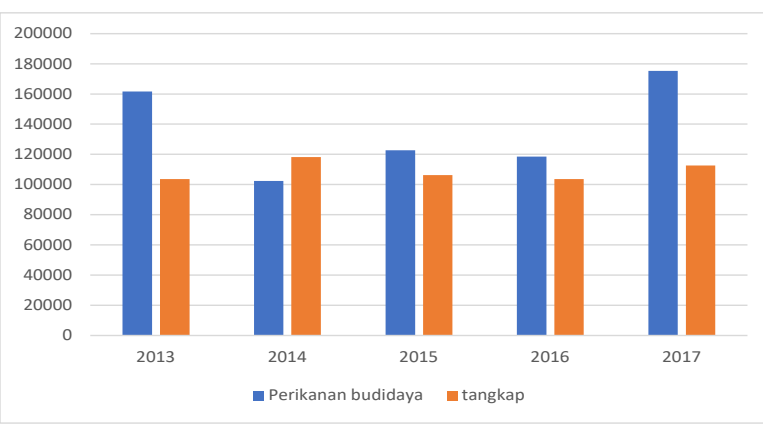

Gambar 2. Produksi Perikanan Provinsi Bali Tahun 2013-2017.

Sumber: BPS Provinsi Bali (2018).

dan budi daya tambak berada pada posisi kedua dengan komoditas utamanya udang vaname. Meskipun jumlah produksinya fluktuatif namun berada di angka yang cukup tinggi setiap tahunnya seperti yang terlihat pada Gambar 3 .

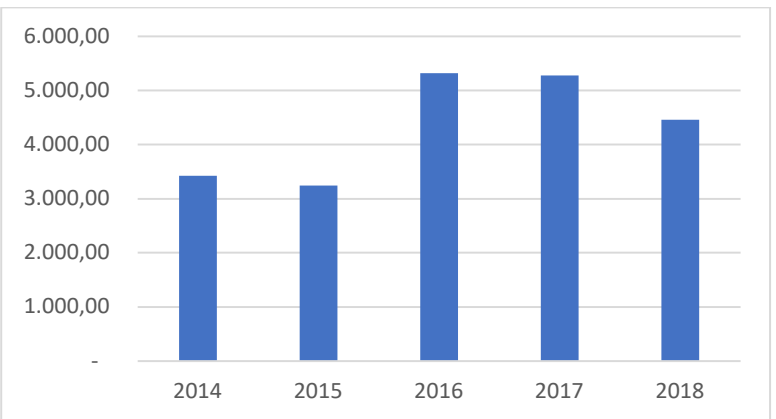

Gambar 3. Trend Produksi Udang Vaname di Provinsi Bali Tahun 2014-2018.

Sumber: DKP Provinsi Bali, 2019.

Pasokan benur diperoleh pembudi daya dari berbagai sumber, baik dari hatchery di Bali atau Situbondo, dengan alasan melihat dari kualitas benur yang dihasilkan, harga jual benur, dan disesuaikan dengan jadwal tebar. Sistem budi daya yang dilakukan bersifat semi intensif dan intensif. Sistem panen yang dilakukan para pembudi daya udang biasanya parsial tidak langsung pada hari ke - 90. Dari 200 ribu benur yang ditebar, pembagian panennya terbagi menjadi:

a) Panen parsial 1 pada hari ke -60 sejumlah 25 $\%$ dari padat tebar (size 70),

b) Panen parsial 2 pada hari ke -75 sejumlah 18 $20 \%$ dari sisa yang belum dipanen (size 42-45),

c) Panen parsial 3 pada hari ke - 90 sisanya yang belum dipanen (size 40-41).

Udang hasil panen dipasarkan melalui satu hingga tiga jalur pemasaran, di antaranya pengumpul, supplier, hingga pengolah. Para pengumpul kecil tersebar di berbagai kabupaten di Bali, namun pada tingkat supplier dan pengolah/ eksportir mayoritas berada di Pulau Jawa (sekitar $85 \%$ berada di Jawa Timur). Atas dasar kondisi pemasaran udang tersebut terlihat bahwa hubungan antara Bali dan Pulau Jawa tepatnya Jawa Timur sangat kuat dan bersifat symbiosis mutualisme (Gambar 4).

\section{KARAKTERISTIK BUDI DAYA UDANG VANAME DI PROVINSI JAWA TIMUR}

Jawa Timur merupakan salah satu provinsi dengan potensi perikanan yang cukup tinggi baik dari perikanan tangkap maupun budi daya. Kontribusi sektor kelautan dan perikanan meningkat secara signifikan tiap tahunnya bagi PDRB Jawa Timur, tercatat pada akhir tahun 2017

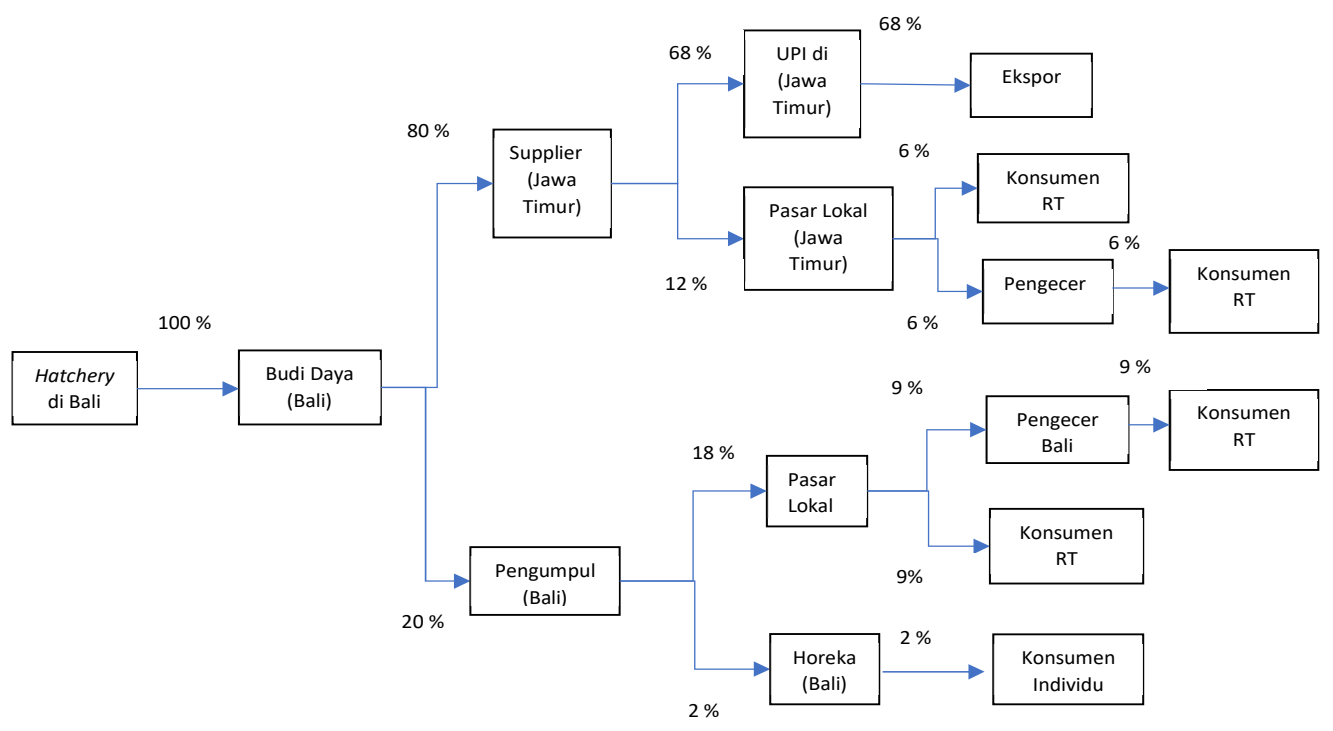

Gambar 4. Rantai Pasok Udang Vaname di Provinsi Bali. 
jumlahnya mencapai 41,89 triliun rupiah atau sebesar 2,48\% (BPS Provinsi Jawa Timur, 2018). Kondisi tersebut tentunya didukung oleh semakin meningkatnya produktivitas perikanan tangkap dan budi daya yang terdiri atas produksi perikanan tangkap 427 ribu ton sedangkan dari produksi perikanan budi daya mencapai 2,2 juta ton.

Produksi perikanan di Jawa Timur selama 5 tahun terakhir mengalami peningkatan secara signifikan. Perikanan budi daya di Jawa Timur dari sub sektor budi daya laut merupakan penyumbang tertinggi dan yang kedua adalah budi daya tambak. Hal ini sejalan dengan kondisi yang ada di lapang terlihat untuk perikanan budi daya terutama di tambak dengan komoditas utamanya adalah udang windu dan udang vaname (Tabel 2).

Udang vaname merupakan salah satu dari lima komoditas utama budi daya tambak di Provinsi Jawa Timur. Budi daya udang vaname di provinsi ini menempati posisi kedua setelah bandeng. Komoditas utama lainnya di Provinsi Jawa Timur, yaitu nila, rumput laut, dan ikan mujaer (Tabel 3).

Tabel 3. Produksi Udang di Provinsi Jawa Timur Tahun 2014-2018 (kg).

\begin{tabular}{ccc}
\hline No & Tahun & Jumlah $\mathbf{( k g )}$ \\
\hline 1 & 2014 & $40.899,0$ \\
2 & 2015 & $51.288,3$ \\
3 & 2016 & $57.782,5$ \\
4 & 2017 & $127.328,3$ \\
5 & 2018 & 69.267 .430 \\
\hline
\end{tabular}

Sumber: Dinas KP Provinsi Jawa Timur, 2018.

Pasokan udang yang masuk ke industri udang yang ada di Surabaya sebagian besar dipasok dari berbagai daerah, di antaranya Gresik dan Lamongan (30\%), Tuban dan Situbondo (30\%), serta $60 \%$ lainnya berasal dari Pati, Rembang, Bali, dan Sumbawa. Ada sebagian besar dijual ke pedagang pengumpul/supplier, namun ada juga sebagian kecil dan langsung dijual ke pengecer untuk selanjutnya dijual ke konsumen masyarakat. Secara keseluruhan, udang dari pembesaran yang ada dijual ke pedagang pengumpul/supplier yang selanjutnya dijual ke perusahaan (UPI) yang selanjutnya diolah menjadi berbagai produk olahan udang untuk kemudian diekspor ke negara-negara, seperti USA, Jepang, dan EU.

Para pembudi daya mengetahui bahwa udang vaname hasil tambak mereka merupakan komoditas ekspor utama dari Indonesia, sehingga target utama penjualan hasil panennya ditujukan ke unit pengolah ikan atau eksportir. Pihak UPI tidak berhubungan langsung dengan pembudi daya sehingga mereka membutuhkan pedagang pengumpul yang disebut juga supplier. Oleh karena itu, pada Gambar 5 menunjukkan bahwa $95 \%$ penjualan hasil panen pembudi daya dijual langsung ke pedagang pengumpul atau supplier, sedangkan sisanya dijual langsung ke pedagang pengecer untuk kemudian dipasarkan ke konsumen rumah tangga. Udang vaname yang dijual langsung ke pengecer biasanya udang dengan ukuran besar atau yang tidak masuk kriteria untuk pengolahan di UPI. Udang yang sudah ada ada di supplier biasanya stok beberapa hari, setelah itu dijual ke UPI yang sudah ada kontrak atau perjanjian kerjasama. Udang vaname tersebut disortir kembali di UPI untuk penyesuaian ukuran sesuai yang dibutuhkan. Udang vaname yang tidak masuk kriteria dikembalikan ke supplier dan ini yang biasanya oleh supplier dijual ke pedagang pengecer.

Tabel 2. Produksi Perikanan di Provinsi Jawa Timur Tahun 2013-2017.

\begin{tabular}{lrrrrr}
\hline \multicolumn{1}{c}{ Sub Sektor } & \multicolumn{5}{c}{ Tahun } \\
\cline { 2 - 6 } & \multicolumn{1}{c}{$\mathbf{2 0 1 3}$} & $\mathbf{2 0 1 4}$ & $\mathbf{2 0 1 5 ^ { * }}$ & $\mathbf{2 0 1 6}$ & $\mathbf{2 0 1 7}$ \\
\hline Perikanan Tangkap & & & & 390.269 & 414.644 \\
Perikanan Laut & 381.574 & 385.879 & - & 17.545 & 12.814 \\
Perikanan Perairan Umum & 13.473 & 13.494 & - & & \\
Perikanan Budi Daya & & & & 640.819 & 540.922 \\
Budi Daya Laut & 580.683 & 601.413 & - & 61.770 & 1.881 \\
Budi Daya Keramba & 346 & 592 & - & 214.025 & 311.666 \\
Budi Daya Tambak & 177.063 & 191.611 & - & 229.401 & 272.730 \\
Budi Daya Kolam & 124.621 & 192.566 & - & 11.555 & 10.888 \\
Budi Daya Jaring Apung & 12.726 & 11.695 & - & 61.770 & 62.874 \\
Budi Daya Sawah dan Mina Padi & 100.509 & 46.011 & - & & \\
\hline
\end{tabular}

Sumber: BPS Provinsi Jawa Timur, 2018

*data tidak tersedia 


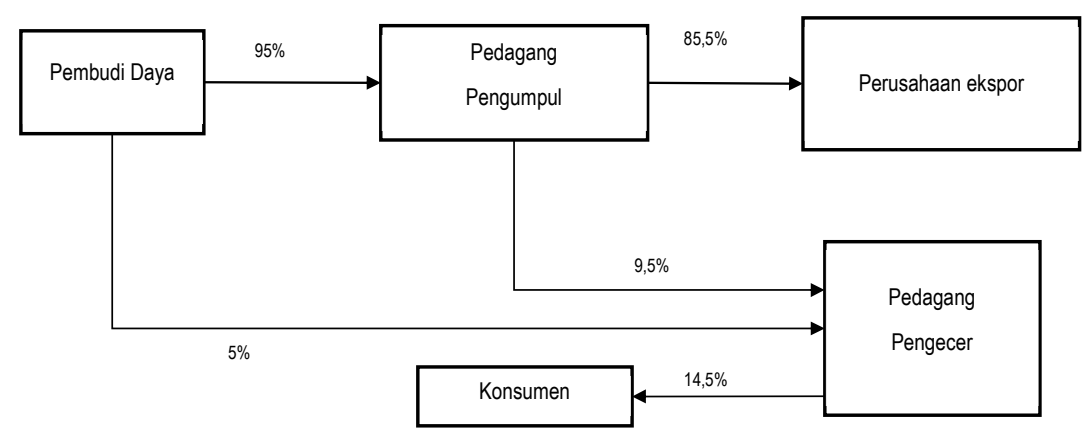

Gambar 5. Rantai Pasok Udang Vaname di Provinsi Jawa Timur.

\section{PENGUKURAN MANAJEMEN RANTAI PASOK BUDI DAYA UDANG VANAME}

Kuesioner penelitian diuji validitasnya pada setiap variabel dan indikator yang diteliti. Kuesioner dianggap valid apabila pertanyaan pada kuesioner mampu mengungkapkan sesuatu yang akan diukur (Ghozali, 2006). Perhitungan uji validitas pada analisis data menggunakan pendekatan SEM6 bisa melihat dari nilai $R$ hitung. Hasil dari perhitungan uji validitas dapat dilihat pada Tabel 4.

Tabel 4. Hasil Uji Validitas tiap Variabel dan Indikator.

\begin{tabular}{cccc}
\hline Variabel & Indikator & $\begin{array}{c}\text { Loading } \\
\text { Factor }\end{array}$ & Validitas \\
\hline Hubungan & $\mathrm{HDPL}_{1}$ & 0,664 & Valid \\
dengan & $\mathrm{HDPL}_{2}$ & 0,782 & Valid \\
& $\mathrm{HDPL}_{3}$ & 0,796 & Valid \\
& $\mathrm{HDPL}_{4}$ & 0,846 & Valid \\
& $\mathrm{HDPL}_{5}$ & 0,849 & Valid \\
\hline Hubungan & $\mathrm{HDPM}_{1}$ & 0,712 & Valid \\
dengan & $\mathrm{HDPM}_{2}$ & 0,806 & Valid \\
Pemasok & $\mathrm{HDPM}_{3}$ & 0,770 & Valid \\
& $\mathrm{HDPM}_{4}$ & 0,847 & Valid \\
\hline Modal Manusia & $\mathrm{MM}_{1}$ & 0,647 & Valid \\
& $\mathrm{MM}_{2}$ & 0,588 & Valid \\
& $\mathrm{MM}_{3}$ & 0,879 & Valid \\
& $\mathrm{MM}_{4}$ & 0,890 & Valid \\
& $\mathrm{MM}_{5}$ & 0,754 & Valid \\
\hline Keunggulan & $\mathrm{KB}_{1}$ & 0,740 & Valid \\
Bersaing & $\mathrm{KB}_{2}$ & 0,898 & Valid \\
& $\mathrm{KB}_{3}$ & 0,706 & Valid \\
\hline Performa & $\mathrm{PB}_{1}$ & 0,788 & Valid \\
Usaha/Bisnis & $\mathrm{PB}_{2}$ & 0,936 & Valid \\
& $\mathrm{PB}_{3}$ & 0,948 & Valid \\
& $\mathrm{PB}_{4}$ & 0,720 & Valid \\
\hline
\end{tabular}

Sumber: Data Primer Diolah, 2019.

Tabel 4 menunjukkan bahwa semua indikator yang digunakan untuk mengukur variabel dalam penelitian ini mempunyai nilai loading factor di atas batas loading factor sebesar 0,5 dan positif (Ferdinand, 2000) sehingga menandakan semua nilai indikator valid untuk digunakan dalam mengukur tujuan penelitian. Selain itu, penilaian kevalidan suatu variabel juga bisa ditentukan berdasarkan nilai dari Average Varians Extract (AVE) seperti yang tercantum pada Tabel 5.

Tabel 5. Hasil Uji Validitas Diskriminan.

\begin{tabular}{lcc}
\hline \multicolumn{1}{c}{ Variabel } & $\begin{array}{c}\text { Average } \\
\text { Varians Extract } \\
\text { (AVE) }\end{array}$ & Keterangan \\
\hline $\begin{array}{l}\text { Hubungan dengan } \\
\text { Pelanggan }\end{array}$ & 0,624 & Valid \\
$\begin{array}{l}\text { Hubungan dengan } \\
\text { Pemasok }\end{array}$ & 0,617 & Valid \\
$\begin{array}{l}\text { Modal Manusia } \\
\text { Keunggulan }\end{array}$ & 0,579 & Valid \\
$\begin{array}{l}\text { Bersaing } \\
\text { Performa Usaha } \\
\text { atau Bisnis }\end{array}$ & 0,617 & Valid \\
\hline Sumber: Data Primer Diolah, 2019. & Valid \\
\end{tabular}

Berdasarkan hasil pengujian validitas diskriminan, seluruh indikator dalam penelitian ini bersifat valid karena memiliki nilai AVE di atas 0.5 (Ferdinand, 2000).

Uji reliabilitas digunakan untuk mengukur suatu kuesioner yang memiliki indikator atau konstruk. Menurut Ghozali (2011) suatu konstruk atau variabel dikatakan reliabel apabila mempunyai nilai cronbach alpha $>0,60$ dan juga nilai composite reliability di atas 0,7 . Hasil penghitungan uji reliabilitas pada semua variabel dalam penelitian ini dapat dilihat pada Tabel 6 .

Tabel 6. Hasil Uji Reliabilitas.

\begin{tabular}{lccc}
\hline \multicolumn{1}{c}{ Variabel } & $\begin{array}{c}\text { Cronbach's } \\
\text { Alpha }\end{array}$ & $\begin{array}{c}\text { Composite } \\
\text { Reability }\end{array}$ & Keterangan \\
\hline $\begin{array}{l}\text { Hubungan } \\
\text { dengan }\end{array}$ & 0,848 & 0,892 & Reliabel \\
$\begin{array}{l}\text { Pelanggan } \\
\text { Hubungan } \\
\text { dengan }\end{array}$ & 0,791 & 0,865 & Reliabel \\
$\begin{array}{l}\text { Pemasok } \\
\text { Modal Manusia }\end{array}$ & 0,812 & 0,870 & Reliabel \\
$\begin{array}{l}\text { Keunggulan } \\
\text { Bersaing }\end{array}$ & 0,688 & 0,827 & Reliabel \\
Performa Bisnis & 0,871 & 0,914 & Reliabel \\
\hline
\end{tabular}


Pengujian selanjutnya yang dilakukan adalah mengidentifikasi seberapa besar kemampuan variabel independen dalam penelitian ini, yaitu hubungan dengan pelanggan, hubungan dengan pemasok, dan modal manusia dapat menjelaskan variabel dependen (Tabel 7).

Tabel 7. Nilai R Squared Adjusted dari Dependent Variable.

\begin{tabular}{lcc}
\hline \multicolumn{1}{c}{ Variabel } & Nilai $R$ squared & $\begin{array}{c}\text { Nilai } R \text { squared } \\
\text { adjusted }\end{array}$ \\
\hline $\begin{array}{l}\text { Keunggulan } \\
\text { Bersaing }\end{array}$ & 0,731 & 0,722 \\
Performa Usaha & 0,852 & 0,850 \\
\hline
\end{tabular}

Dari Tabel 7, nilai $R$ Square Adjusted untuk Performa Usaha (PU) adalah 0,850 (85\%), yang artinya adalah kemampuan variabel independen menjelaskan variabel dependen performa usaha adalah $85 \%$ dan sisanya dijelaskan oleh variabel independen lain yang tidak ada di dalam model yang dirumuskan dalam penelitian ini. Kemampuan variabel independen menjelaskan variabel dependen keunggulan bersaing adalah $72,2 \%$ dan sisanya dijelaskan oleh variabel independen lain yang tidak ada di dalam model penelitian ini.

Uji selanjutnya yang dilakukan adalah $U_{j i}$ Goodness of Fit (GoF) atau uji kesesuaian antara hasil pengamatan tertentu dengan frekuensi yang diperoleh berdasarkan nilai harapannya. Menurut Tennenhaus, Amato, S, \& Vinzi (2004), GoF pada perhitungan PLS-SEM harus dicari secara manual dengan rumus sebagai berikut:

$$
\mathrm{GoF}=\sqrt{A V E} x R 2
$$

Hasil penghitungan nilai GoF dapat dikelompokkan sebagai berikut:

GoF $=0-0,25$ artinya kecil (small)

GoF $=0.25-0,36$ artinya moderat

$\mathrm{GoF}=>0,36$ artinya besar.

Kriteria tersebut senada dengan pernyataan K7atos (2010), bahwa nilai GoF harus di atas 0,80 sehingga semua indikator mampu menjelaskan konstruk. Dari hasil perhitungan GoF di atas diperoleh nilai 0,788 sehingga dapat disimpulkan bahwa model memiliki nilai GoF yang besar dan semakin besar nilai GoF maka semakin sesuai dalam menggambarkan sampel penelitian. Tahap berikutnya pengujian hipotesis yang dilakukan berdasarkan nilai $t$ dan nilai $p$ dari suatu hubungan dari hasil pengolahan SEM. Hipotesis penelitian yang diajukan sebelumnya akan diuji dan dibahas berdasarkan hasil dari bootstrapping (Tabel 8).

Pengujian hipotesis dengan melihat nilai dari $t$ statistic dan $p$ value pada masing-masing variabel independen dan dependen. Suatu pengujian dinilai signifikan dan berpengaruh jika memiliki nilai $t$ statistic di atas 1,96.

\section{PENGARUH INDIKATOR MANAJEMEN RANTAI PASOK}

\section{Hubungan dengan Pelanggan terhadap Keunggulan Bersaing}

Hubungan dengan pelanggan adalah mengevaluasi hubungan antara penyedia dan penerima barang mulai dari hulu hingga ke hilir dalam suatu rantai pasok (Lee et al., 2007). Hubungan yang baik dengan pelanggan bisa membantu penyedia layanan untuk mendapatkan informasi secara lengkap mengenai kebutuhan pelanggan sehingga bisa meningkatkan kinerja perusahaan. Pada penelitian ini, hubungan dengan pelanggan diwujudkan pada hubungan antara pembudi daya dengan pelanggan mulai dari awal hingga akhir. Pelanggan bagi pembudi daya dalam usaha budi daya udang vaname terdiri dari pedagang pengumpul, supplier, dan konsumen akhir (rumah tangga, restoran, dan hotel). Antara pembudi daya dengan pelanggan perlu melakukan perencanaan bersama dan melakukan upaya pemecahan masalah bersama antara keduanya (Gunasekaran, Patel, \& Mc Gaughey, 2004).

Hubungan dengan pelanggan dapat diukur dengan adanya pertukaran informasi yang baik,

Tabel 8. Hasil Uji Hipotesis.

\begin{tabular}{cccccc}
\hline $\begin{array}{c}\text { Hubungan } \\
\text { Indikator }\end{array}$ & $\begin{array}{c}\text { Original Sample } \\
(\mathbf{O})\end{array}$ & $\begin{array}{c}\text { Sample Mean } \\
(\mathbf{M})\end{array}$ & $\begin{array}{c}\text { Standard Deviation } \\
\text { (STDEV) }\end{array}$ & T Statistic & $P$ Values \\
\hline $\mathrm{HDPI} \rightarrow$ KB & $-0,018$ & $-0,019$ & 0,097 & 0,186 & 0,852 \\
$\mathrm{HDPm} \rightarrow$ KB & 0,330 & 0,327 & 0,127 & 2,593 & 0,010 \\
$\mathrm{MM} \rightarrow$ KB & 0,612 & 0,618 & 0.079 & 7,762 & 0,000 \\
$\mathrm{~KB} \rightarrow \mathrm{PU}$ & 0,923 & 0,923 & 0,015 & 61,619 & 0,000 \\
\hline
\end{tabular}

Sumber: Data Primer Diolah, 2019 
pengiriman barang yang sesuai dengan waktu pemesanan, jumlah yang tepat dan sesuai dengan invoice atau faktur yang ada. Selain itu, komitmen antara penyedia dan pelanggan untuk menyepakati perjanjian jual beli juga bisa menjadi indikator pengukur hubungan ini. Menurut penelitian yang dilakukan oleh Lee et al. (2007) menyimpulkan bahwa hubungan dengan pelanggan memberikan dampak positif pada keunggulan bersaing suatu perusahaan.

Nilai $p$ value pada pengaruh hubungan dengan pelanggan terhadap keunggulan bersaing sebesar 0,852 dengan $t$ statistik sebesar 0,186. Nilai $p$ value $>0,05$ dan nilai $t$ statistic di bawah 1,96 menunjukkan bahwa variabel hubungan dengan pelanggan tidak berpengaruh terhadap keunggulan bersaing (hipotesis 1 ditolak).

Hal ini menunjukkan hubungan pembudi daya dengan pelanggan (pengumpul, supplier, dan konsumen pribadi) tidak memiliki efek penting bagi keunggulan bersaing. Meskipun antara seorang pembudi daya memiliki pertukaran informasi yang baik dan sistem jual beli yang baik sesuai kesepakatan dengan pelanggan ternyata tidak menjadi salah satu indikator yang menentukan bahwa pembudi daya tersebut unggul dibandingkan dengan pembudi daya lainnya. Kondisi tersebut karena secara riil di lapangan untuk pasar udang bukan hanya melihat dari pelayanan tapi juga tergantung permintaan di pasar. Jika permintaan tinggi maka pelanggan bisa dengan bebas membeli udang ke pembudi daya manapun tanpa ada ikatan.

\section{Hubungan dengan Pemasok terhadap Keunggulan Bersaing}

Salah satu kunci utama untuk menciptakan manajemen rantai pasok yang efektif, yaitu menjadikan para pemasok sebagai mitra dalam strategi perusahaan untuk memenuhi permintaan pasar yang fleksibel (Heizer \& Render, 2005). Hubungan dengan pemasok ini mengukur sejauh mana respon pemasok terhadap permintaan input produksi, bagaimana kualitas pertukaran informasi antara pemasok dengan penyedia layanan, bagaimana sistem pengiriman yang diandalkan dan menjadi keunggulan dari masing-masing pemasok dan bagaimana komitmen atau rasa percaya yang terbentuk di antara keduanya.

Pada usaha budi daya udang vaname pemasok, artinya penyedia input produksi di antaranya hatchery atau penyedia benih, penyedia pakan, dan sarana produksi perikanan lainnya. Tentunya masing-masing penyedia input produksi tersebut tidak hanya satu orang tapi bisa banyak tergantung kerja sama yang dilakukan oleh pembudi daya udang vaname. Adanya kerja sama dengan supplier yang dapat diandalkan akan menghasilkan pengertian dan pemahaman yang baik akan kebutuhan dan keperluan masing-masing pihak sehingga dapat meningkatkan penghasilan perusahaan (Cempakasari \& Yoestini, 2003). Selain itu, berdasarkan hasil penelitian yang dilakukan oleh Lee et al. (2007) menyampaikan bahwa hubungan dengan pelanggan berdampak positif pada keunggulan bersaing suatu perusahaan.

Nilai $p$ value pada pengaruh hubungan dengan pemasok terhadap keunggulan bersaing adalah 0,010 dengan nilai $t$ statistic sebesar 2,593 dan tanda koefisiennya positif. Nilai $p$ value $<0,05$ dan nilai $t$ statistic melebihi 1,96 serta bertanda positif menunjukkan bahwa variabel hubungan dengan pemasok berpengaruh positif dan signifikan terhadap keunggulan bersaing (Hipotesis 2 diterima). Semakin baik hubungan dengan pemasok maka semakin baik keunggulan bersaing.

Berdasarkan hasil penelitian disimpulkan bahwa keandalan dalam pengiriman dan respon permintaan yang cepat dominan dalam membentuk hubungan dengan pemasok. Semakin cepat responnya akan memberikan nilai lebih terhadap pemasok dan membangun hubungan yang baik. Apabila input produksi (benih dan pakan) dalam suatu budi daya udang vaname selalu tersedia kapan saja maka bisa menjaga keberlangsungan usaha budi daya itu sendiri. Stok input produksi yang aman sepanjang tahun memberikan seorang pembudi daya menjadi lebih unggul dibanding pembudi daya lainnya. Hal ini karena mereka bisa kapan saja melakukan tebar benih dan panen sehingga permintaan pasar juga bisa selalu terpenuhi. Kondisi tersebut bisa membuat pelanggan untuk kembali membeli udang dari pembudi daya yang sama.

\section{MODAL MANUSIATERHADAPKEUNGGULAN BERSAING}

Menurut Bakshi (2015) modal manusia menunjukkan bagaimana efisiensi dari sebuah organisasi dalam menggunakan sumber daya manusianya baik dari segi pengalaman, pemahaman, keahlian, kompetensi, dan kreativitas untuk menciptakan nilai dari organisasi tersebut. 
Pentingnya investasi pada modal manusia sebagai sarana untuk mempresentasikan kondisi dari perkembangan dan keberhasilan semua organisasi (Todericiu \& Stanit, 2015).

Modal manusia pada usaha budi daya udang vaname lebih ditekankan pada individu yang mengelola secara langsung tambak-tambak udang atau yang biasa disebut teknisi dan anak kolam. Pentingnya penekanan tersebut karena pada usaha budi daya di beberapa kasus pemilik tambak tidak turun langsung dalam mengelola usahanya dan mempekerjakan orang lain. Kemampuan dan keahlian lain yang dimiliki teknisi di masing-masing tambak tentunya memiliki pengaruh yang berbedabeda. Pengukuran selanjutnya adalah aspek-aspek sosial di antaranya kepercayaan (trust), transfer informasi, dan kemampuan belajar dari para teknisi dan anak kolam. Hal tersebut karena menurut Champion \& Fearne (2001), aspek-aspek sosial tersebut mempengaruhi kinerja, pengembangan, dan keberhasilan rantai pasok. Berdasarkan penelitian yang dilakukan oleh Kamukama (2013) menyampaikan bahwa modal manusia memberikan dampak positif pada keunggulan bersaing suatu perusahaan.

Modal manusia yang dimaksudkan pada usaha budi daya udang vaname adalah orang-orang yang mengelola secara langsung tambak tersebut, biasanya dikenal dengan istilah teknisi dan anak kolam. Teknisi adalah pihak yang bertanggung jawab secara penuh untuk pengelolaan tambak mulai dari pra budi daya hingga panen selesai dan anak kolam yang membantu teknisi untuk kegiatan rutin seperti pemberian pakan, pembersihan air, dan membantu panen. Pemahaman budi daya udang vaname yang dimiliki teknisi dan "anak kolam" menjadi indikator yang dominan pada variabel ini. Semakin banyak ilmu pengetahuan budi daya yang dimiliki teknisi dan didukung pula oleh kejujuran serta terciptanya komunikasi yang baik menjadi nilai lebih pada tambak tersebut. Semakin tinggi nilai tambah maka keunggulan bersaing semakin tinggi.

Nilai $p$ value pada pengaruh modal manusia terhadap keunggulan bersaing adalah 0,000 dengan nilai koefisien positif dan nilai $t$ statistic sebesar 7,762 . Nilai $p$ value $<0,05$ dan nilai $t$ statistic $>1,96$ menunjukkan bahwa variabel modal manusia memiliki pengaruh yang positif dan signifikan terhadap keunggulan bersaing. Artinya, semakin baik modal manusia yang dimiliki suatu budi daya udang vaname maka semakin baik keunggulan bersaing yang dimiliki (hipotesis 3 diterima). Hasil ini sejalan dengan apa yang disampaikan oleh Ramadan \& Kusumardhani (2017) bahwa dengan modal manusia yang baik bisa menjadi dasar untuk menjalankan sistem manajemen di perusahaan sehingga bisa memiliki keunggulan bersaing.

\section{PENGARUH KEUNGGULAN BERSAING TERHADAP PERFORMA USAHA BUDI DAYA UDANG VANAME}

Keunggulan bersaing adalah kemampuan sebuah organisasi untuk melakukan kegiatan atau aktivitasnya yang para kompetitor tidak bisa melakukan, dan dengan pertimbangan harga yang lebih rendah, atau keunggulan yang dapat mengungguli produk pesaing. Keunggulan bersaing mempresentasikan strategi yang baik (Todericiu \& Stanit, 2015). Keunggulan bersaing dapat dinilai dari beberapa indikator, seperti harga, kualitas, pengiriman, dan fleksibilitas, serta inovasi produk (Banerjee \& Mishra, 2015). Performa atau kinerja usaha merupakan hasil evaluasi terhadap pekerjaan yang telah dilakukan dibandingkan dengan kriteria yang telah ditetapkan bersama (Rai, 2008).

Keunggulan bersaing pada usaha budi daya udang vaname maksudnya keunggulan yang dimiliki masing-masing petambak dari usahanya yang bisa menjadi nilai jual lebih bagi para pelanggan. Dalam penelitian ini, keunggulan bersaing bisa diukur dari kualitas produk yang dilihat dari size udang yang dihasilkan, fleksibilitas pasar sarana menjual udang, dan sistem budi daya yang dijalankan sudah sesuai dengan sistem yang diinisiasi oleh pemerintah dalam CBIB (Cara Budi daya Ikan yang Baik). Keunggulan bersaing memberikan dampak positif bagi performa usaha suatu perusahaan (Banerjee \& Mishra, 2015).

Nilai $p$ value pada pengaruh keunggulan bersaing terhadap performa usaha adalah 0,000 dengan nilai $t$ statistic sebesar 61,619 menandakan keduanya memenuhi persyaratan signifikansi. Hal ini menunjukkan variabel keunggulan bersaing berpengaruh positif dan signifikan terhadap performa usaha. Semakin baik keunggulan bersaing maka semakin baik performa usaha, begitu pula sebaliknya. Hal ini berarti hipotesis diterima, kondisi ini mendukung hasil penelitian yang dilakukan Rahadi (2012) yang menghasilkan kesimpulan bahwa supply chain management berpengaruh positif dan signifikan terhadap kinerja operasional perusahaan. 
Hasil tersebut menunjukkan pentingnya efek keunggulan bersaing terhadap performa usaha. Pembudi daya yang menghasilkan kualitas udang yang lebih baik, respon pasar yang cepat dan melakukan sistem budi daya sesuai CBIB dianggap akan mendapatkan performa usaha yang baik. Sistem budi daya sesuai CBIB menjadi faktor yang dominan karena udang vaname merupakan komoditas ekspor yang saat ini ketelusuran hingga hulu menjadi hal penting dalam perdagangan internasional. Sehingga udang yang dihasilkan oleh para pembudi daya yang sudah menerapkan CBIB dengan tepat menjadi lebih unggul dan dicari oleh banyak supplier dan pasar di luar negeri. Selain itu, pentingnya peningkatan interaksi antar penyusun rantai pasokan akan meningkatkan kemampuan organisasi untuk memenuhi tujuan yang diinginkan dari suatu perusahaan (Deshpande, 2012).

\section{PENUTUP}

Variabel yang tidak bisa diukur langsung terhadap performa usaha budi daya udang vaname di Provinsi Bali dan Jawa Timur terdiri dari variabel hubungan dengan pelanggan, hubungan dengan pemasok, modal manusia, dan keunggulan bersaing. Hasil pengujian menunjukkan bahwa variabel hubungan dengan pelanggan tidak berpengaruh secara positif terhadap variabel keunggulan bersaing. Sementara itu, variabel hubungan dengan pemasok, modal manusia, dan keunggulan bersaing berpengaruh secara positif terhadap performa usaha budi daya udang vaname.

Pembudi daya udang vaname yang memiliki keunggulan bersaing menyebabkan performa usaha dari budi daya tersebut juga akan semakin baik. Komponen manajemen dari pemasok, pelanggan, serta internal perusahaan berupa modal manusia yang baik dapat meningkatkan performa usaha, seperti omset, keuntungan, kualitas produk, dan ketersediaan udang sepanjang tahun. Intervensi dari pemerintah melalui peningkatan kompetensi budi daya yang dimiliki para pembudi daya bisa menjadi kunci untuk peningkatan keunggulan bersaing pembudi daya di level domestik maupun internasional.

\section{UCAPAN TERIMA KASIH}

Penulis mengucapkan rasa terima kasih kepada Dinas Kelautan dan Perikanan Provinsi Bali dan Jawa Timur dalam membantu ketersediaan data yang dibutuhkan dalam penelitian. Tak lupa penulis juga mengucapkan terima kasih kepada tim peneliti Model Penerapan Sistem Logistik Perikanan Budidaya serta Penggunaan DSS untuk Perikanan Budidaya Berkelanjutan Tahun 2019.

\section{PERNYATAAN KONTRIBUSI PENULIS}

Dengan ini kami menyatakan bahwa kontribusi masing-masing penulis terhadap pembuatan karya tulis adalah Rismutia Hayu Deswati sebagai kontributor utama, serta Lathifatul Rosyidah dan Tenny Apriliani sebagai kontributor anggota. Penulis menyatakan bahwa telah melampirkan surat pernyataan kontribusi penulis.

\section{DAFTAR PUSTAKA}

Adha, W. M. (2017). Integrasi Rantai Pasok terhadap Kinerja dan daya saing kakao. Jurnal Bisnis Darmajaya Vol 03 No 02.

Bakshi, H. C. (2015). Examining intellectual capital and competitive advantage relationship: role of innovation and. International Journal of Bank Marketing.

Banerjee, M. \& Mishra, M. (2015). Retail Supply Chain Management Practices in India: A Business Intelligence Perspective. Jurnal of Reatailing and Costumer Sevices, 12

Barney, J. B., dan Hesterley, W. S. (2008), Strategic management and competitive advantage, Upper Saddle River, New Jersey: Pearson Prentice Hall

[BPS] Badan Pusat Statistik Provinsi Bali. (2018). Provinsi Bali dalam Angka 2018. Bali.

[BPS] Badan Pusat Statistik Provinsi Bali. (2019). Produk Domestik Regional Bruto Menurut Lapangan Usaha 2015-2019. Bali

[BPS] Badan Pusat Statistik Provinsi Jawa Timur. (2018). Provinsi Jawa Timur Dalam Angka Tahun 2018. Jawa Timur

Brown, W. J. (2003). Agribusiness Cases in Supply Chain Management. Paper. IFMA Congress.

Cempakasari, D. A., \& Yoestini. (2003). Studi Mengenai Pengembangan Hubungan Jangka Panjang Perusahaan Dan Pengecer. Jurnal Sains Pemasaran Indonesia. Vol II, No. 1.

Champion, S. C., \& Fearne, A. P. (2001). Supply Chain Management: A First Principles Consideration of Its Application to Wool Marketing. Jurnal Wool Technology of Sheep Breeding Vol. 49 (3). Hal. 222-236.

Deshpande, A. (2012). Supply Chain Management Dimensions, Supply Chain Performance and Organizational Performance: An Integrated Framework. International Journal of Business and Management Vol 7. 
[DKP] Dinas Kelautan dan Perikanan Provinsi Bali. (2019). Statistik Perikanan Budidaya Tahun 2019. Bali

[DKP] Dinas Kelautan dan Perikanan Provinsi Jawa TImur. (2018). Statistik Perikanan Budidaya Tahun 2018. Jawa Timur

Ferdinand, A. (2000). Structural Equation Modelling dalam Penelitian Manajemen. Semarang: Penerbit Universitas Diponegoro

Ghozali, I. (2006). Aplikasi Analisis Multivariate dengan Program SPSS. Semarang. Badan Penerbit Undip.

Ghozali, I. (2011). Aplikasi Analisis Multivariate dengan Program IBM SPSS 19 (5 ed.). Semarang: BP Universitas Diponegoro.

Goyal, S. K, \& Cardenas-Barron, L. E. (2001). Note on: An Optimal Batch Size for a Production System Operating Under a Just in Time Deivery System. International Journal of Production Economics.

Gunasekaran, A., Patel, C., \& Mc Gaughey, R. E. (2004). A framework for supply chain performance measurement. International Journal of Production Economics, Vol 87 (333-347), USA

Hair, J. F., Ringle, C. M., Marko, S. (2011). PLS-SEM: Indeed a Silver Bullet. Journal of Marketing Theory and Practice, vol 19 no 2 (139-151)

Heizer, J., \& Render, B. (2005). Management Operasi. Jakarta: Salemba Empat.

Grant, D. B. (2012). Logistics Management. Pearson Education, Harlow UK.

Gunasekaran, A., \& Ngai, E. W. T. (2012). The future of operations management: An outlook and analysis', International Journal of Production Economics 135(2),687-701.

Hassini, E., Surti, C., \& Searcy, C. (2012). A literature review and a case study of sustainable supply chains with a focus on metrics', International Journal of Production Economics In press (0), URL: http://www.sciencedir ect.com/science/ article/pii/ S0925527312000576.

Kamukama, N. (2013) 'Intellectual Capital: Company's Invisible Source of Competitive Advantage', International Business Journal, 23(3), pp. 260-283.

Katos, A. V. (2010). The influence of information and communication technologies on enabling trade: a cross-country investigation, Journal of Information Technology Impact, Vol. 10 No. 1, pp. 15- 24.

Lee, C. W., G. Kwon, I. W., \& Severance, D. (2007). Relationship between supply chain performance and degree of linkage among supplier, internal integration, and costumer. 10.
Mentzer, J. T. (2008). Rigor versus relevance: why would we choose only one? Journal of Supply Chain Management 44(2), 72-77.

Pujawan, I. N., \& Mahendrawathi, E. R. (2010). Supply Chain Management. Edisi 2. Surabaya: Guna Widya.

Rahadi, D. R. (2012). "Pengaruh Supply Chain Management Terhadap Kinerja Operasional Perusahaan". Proceeding Seminar Sistem Produksi X.

Rahmasari, L. (2011). Pengaruh Supply Chain Management terhadap Kinerja Perusahaan dan Keunggulan Bersaing (Studi Kasus pada Industri Kreatif di Provinsi Jawa Tengah). Jurnal IImiah Informatika, Vol 2, No. 2

Rai, I. G. A. (2008). Audit Kinerja Pada Sektor Publik: Konsep, Praktik, Studi Kasus. Jakarta: Salemba Empat.

Ramadan, Y. S., \& Kusumawardhani, A. (2017). Analisis Pengaruh Manajemen Rantai Pasokan terhadap Performa Bisnis (Studi: Pedagang Grosir Tradisional Makanan dan Minuman Ringan Tradisional di Kabupaten Banyumas). Diponegoro Journal of Management Volume 6 No 3.

Simchi-Levi, D., Kaminsky, P., \& Simchi-Levi, E. (2008). Designing and Managing the Supply Chain. New York: The McGraw-Hill.

Smith, D. A., \& Langfield-Smith, K. M. (2004). Structural Equation Modeling in Management Accounting Research: Critical Analysis and Opportunities. Journal of Accounting Literature, 23, 49-86.

Sugiyono. (2013). Metode Penelitian Pendidikan Pendekatan Kuantitatif, Kualitatif, dan R\&D. Bandung: Alfabeta.

Tennenhaus, M., Amato, S., \& Vinzi, V. E. (2004). A Global Goodness of-Fit Index for PLS Structural Equation Modelling", Proceedings of The XLII SIS Scientific Meeting, Vol. Contibuting Papers, CLEUP, Padova, pp. 739-742.

Todericiu, R., \& Stanit, A. (2015). Intellectual Capital The Key for Subtainable Competitive Advantage for the SME's Sector. 6.

Wuwung, S. C. (2013). Manajemen Rantai pasokan Produk Cengkeh pada Desa Wawona Minahasa Selatan. Jurnal EMBA 1 (3): 230-238. 